\title{
The IHO as Actor The case of cannabis and the Single Convention on Narcotic Drugs 1961
}

\author{
James H. Mills
}

\section{The early years of the CND}

7 he Commission on Narcotic Drugs (CND) was appointed at the first meeting of the United Nations Economic and Social Council in New York in $1946^{1}$ and one of its first actions was to broaden its remit; the Paris Protocol of 1948 brought the wide range of new synthetic drugs that had emerged during the 1940s under existing controls on the advice of the WHO. The Commission did not neglect more longstanding interests, however, and quickly attempted to impose a world-wide monopoly on opium. ${ }^{2}$ This met with some resistance on the part of the world's opium producers and was eventually watered down in the 1953 Protocol on Opium, which never actually came into force. ${ }^{3}$ The chief concern of the Commission throughout the 1950 s was to come up with a simplified system to replace the various treaties devised in the 1920s and 1930s and the Single Convention on Narcotic Drugs of 1961 was eventually to satisfy this ambition.

The confusion and curiosity in international policy circles about cannabis in the inter-War period was replicated early in the 1950s. The sub-Committee on Cannabis established by the League of Nations in the 1930s had petered out due to the outbreak of hostilities. ${ }^{4}$ During its six years of collecting information and opinions the sub-Committee only managed to conclude that 'certain points still require clarification, especially in connection with the physiological and psychological and psychopathic effects of cannabis and with the relationships between hashish

1 British Library (BL), UN Documents Collection (UN), E/34 27th February 1946.

2 The UN and Narcotic Drugs: Half a century of successful struggle against crime, disease and social affliction, (New York, 1960), pp. 12-17.

3 A. Lande, "The Single Convention on Narcotic Drugs, 1961", International Organization, 16, (1962), 782.

4 See chapter 2 of J. Mills, Cannabis Nation: Control and consumption in Britain, 19282008, (Oxford, 2012). 
addiction and insanity and between cannabis addiction and addiction to other drugs especially heroin'. Perhaps because so little progress had been made in the 1930s towards a clear and agreed approach to the drug, the issue of cannabis remained largely neglected at the United Nations in its early years. The Progress Report on the Work of the Division of Narcotic Drugs for the period between May 1949 and March 1950 noted that 'the Division's preoccupations with the many matters with which the present report deals, coupled with the absence of its officials on missions, have made it impossible to give the studies on cannabis as much attention as would have been desirable'. It noted that Professor Bouquet, who had sat on the subCommittee on Cannabis in the 1930s, had been contacted by the Division and that it had also been at pains to collect much of the information of the previous decade on the chemical nature of cannabis. It also noted a recent report in the Lancet on withdrawal symptoms in Cannabis addicts. However, it gave the sense that matters related to the drug were proceeding much as they had in the 1930s, at a leisurely pace in which the collection of information seemed to be the central objective. ${ }^{6}$

The Secretary-General of the United Nations quickly changed the pace of action on cannabis with the first draft of the proposed single convention on narcotic drugs which was unveiled in 1950. It had been agreed that his office should prepare this to get the ball rolling on the process of agreeing a single convention. ${ }^{7}$ When the Secretariat presented its ideas on $27^{\text {th }}$ February 1950 the proposals for cannabis were radical. Two alternative approaches to the substance were on offer. Both assumed that recreational consumption was bad and ought to be rigorously discouraged. However, the first alternative also worked on the assumption that cannabis had no legitimate medical use that could not be met by other 'less dangerous substances'. It proposed that the production of Indian hemp be entirely prohibited save for those small amounts necessary for scientific experimentation.

The second alternative worked on the assumption that cannabis did have legitimate medical uses. In this case each national state would have to establish a monopoly which had the exclusive right to produce cannabis and trade in it. Each government would be expected to select from a range of measures to ensure that no cannabis leaked out of the system into 'illicit traffic', measures that included starting state-run cannabis farms and the systematic uprooting of wild plants. In countries

5 British Library (BL), League of Nations Collection (LN), Advisory Committee on Traffic in Opium and other Dangerous Drugs (AC), S.P.R. Mic. B 23/12, C.237.M.136.1938.XI. $A C$, report to the council on the work of the twenty-third session June 7th to June 24th 1938, pp. 9 and $26-27$.

6 BL, United Nations collection (UN), E/CN.7/196. UN Economic and Social Council 21 st June 1950, Progress report on the work of the division of narcotic drugs for the period 16th May 1949 to 31st March 1950, p. 43.

7 BL, UN, E/1673. UN Economic and Social Council 27th April 1950, Procedure regarding draft single convention on narcotic drugs, p. 1. 
where there was significant consumption of cannabis products for recreational purposes, it was proposed that 'a reservation' be made that allowed the continued production of cannabis for this market. However, this was on the strict condition that this reservation would 'cease to be effective unless renewed by annual notification made to this effect and accompanied by a description of the progress in the preceding year towards the abolition of such non-medical use and by an explanation of the continued reasons for the temporary retention of such use'. ${ }^{8}$ In other words, the starting-point for discussions had cut through the patient dithering over voluminous and contradictory evidence which had marked the League of Nations approach and that of the early United Nations. It boldly asserted that all non-medical consumption of cannabis was harmful and proposed that countries where recreational use was common should be obliged to tackle the habit among their people. Indeed, the possibility that cannabis was entirely useless as a medicine had also been formally recognised in the draft treaty, although only as an option. This draft was considered at the $5^{\text {th }}$ session of the Commission on Narcotic Drugs at New York on Friday December $1^{\text {st }} 1950$.

It is not difficult to explain why this firm stance on cannabis was taken as William McAllister has argued that an 'inner circle' of control-advocates was in the ascendant at the UN in the late 1940s and early 1950s and was determined to set a 'radical' agenda on questions related to narcotics. 'However, the report of the 5 th session of the Commission on Narcotic Drugs which discussed the draft convention shows that national delegates did not immediately agree on which of the two options to back, 'many members of the Commission thought that Indian hemp drugs have no medical value and, consequently, expressed themselves in favour of the first alternative ... other members did not share this view and gave preference to the second alternative'. The records of this meeting show that the representative of the USSR took the initiative to secure the first alternative which was for total prohibition. He was supported by Egypt, Turkey and Mexico among others but France and the Netherlands were chief among those that resisted. The latter argued that it preferred to leave to its physicians the freedom to choose between medicines, and so therefore favoured control rather than prohibition. The former was also concerned about prohibiting a therapeutic which was currently recommended by the French Academy of Medicine. Iran and India voiced their opinion that 'the question should be thoroughly studied before any decision was taken' and the representative of the USA concurred. ${ }^{10}$ The attempt to take decisive action on cannabis by the

8 BL, UN, E/CN.7/AC.3/3. Draft of the Single Convention, 27th February 1950, pp. $32-35$.

9 W. McAllister, Drug Diplomacy in the twentieth-century: An international history, (London, 2000), pp. 156-157.

10 BL, UN, E/CN.7/SR.117. Commission on Narcotic Drugs Fifth Session Summary Record of the Hundred and Seventeenth Meeting 10th December 1950, pp. 7-9. 
Secretariat stalled, as the Commission concluded that before agreement was likely, it would be necessary to undertake more studies in order to determine whether the control measures proposed in the second version of Section 33 or any other measures would, in practice, prove effective'. 'Indeed, the misgiving that 'a rigid limitation of the use of drugs under control to exclusively medical and scientific needs does not sufficiently take into consideration long established customs and traditions which persist in particular in territories of the Middle and Far East and which it is impossible to abolish by a simple degree of prohibition' seemed to suggest that even the attempt to impose consensus on recreational, non-medical use was to be challenged.

With the issue of cannabis once again deferred for more information, the Secretary-General of the Commission on Narcotic Drugs wearily reported in 1953 that 'there are a number of major difficulties inherent in the problem of Indian hemp which makes it very hard to decide what measures would be most effective in leading to its solution'. ${ }^{13}$ It noted among these the lack of agreement on its medical value, the traditions of recreational and ritual use in parts of the world, the industrial use of the plant and its ready availability in wild and remote areas. The Secretariat proposed a number of new studies and it is interesting to glimpse the ways in which the Secretariat's call for more information carried within it a presumption about the outcome of this gathering process. The Secretary-General's note was prepared for the consideration of the Commission as follows:

The Commission may wish to give the Secretariat instructions on the scope of these studies and to formulate more precisely the subject-matter which they should include. It is thought that the studies fall naturally into two categories as follows:

1. Those that address themselves to the factual situation;

2. Those that aim at evaluating and interpreting that situation with a view to adjusting the present control regime for Indian hemp which has become outmoded by changing circumstances to present day condition.

So that everyone was clear that the 'present day condition' was an unhappy one, the Secretariat included in its note a couple of statements. It began with the observation that seizures in 1951 were over ten times that of 1945 . The UK was then used as an example of a country that was experiencing increased use of Indian hemp as a pleasure drug' and the government's report to the UN was quoted as showing 'there

11 BL, UN, E/CN.7/216. Report of the Commission on Narcotic Drugs (Fifth Session), p. 38 .

12 Ibid., p. 25.

13 BL, UN, E/CN.7/256. The Problem of Indian Hemp, Note by the Secretary-General 19th March 1953, p. 3. 
has been a considerable increase in the traffic in Indian hemp in recent years, so that this drug now accounts for more than half the seizures made by H.M. Customs'. This was a particularly selective reading of the cannabis situation in the UK at this time, as Home Office officials had observed in an internal review of 1952 that 'the picture is as before, a small drug problem kept within narrow bounds by a rigid system of control ... there is still no sign of a widespread, organised traffic, of violent crime arising from the habit, or of the white inhabitants taking to the habit to any degree'. ${ }^{14}$ Indeed, at the next meeting of the Commission the UK delegate made a point of protesting that 'the smoking of Indian hemp was still a new and relatively minor problem in his country'. ${ }^{15}$ Nevertheless, the selective reading of the situation in the UK, when taken together with the tone of the Secretariat's note, leaves the impression that the proposal to seek more information about cannabis was not driven by a sense that the issue was an open one, but rather was based on a feeling that more evidence was needed for the prosecution. The Secretariat's proposed call for information was approved by the Commission at its meeting in 1953, which was particularly keen for data on the 'physical and mental effects of the use of Indian hemp' and which agreed that the term 'cannabis' ought to replace Indian hemp in all future discussions and regulations. ${ }^{16}$

In gathering the research on cannabis the Secretariat decided to target countries where cannabis use was common. The WHO was given the responsibility of tackling the survey of the physical and mental health issues. This recognised the previous efforts of the WHO's Expert Committee on Habit Forming Drugs to cut through the confusion on cannabis. Established in 1949, this Committee met for only five days in that year and for the same in 1950 and 1952 before declaring that

It was of opinion that cannabis preparations are practically obsolete. So far as it can see, there is no justification for the medical use of cannabis preparations. ${ }^{17}$

The vice-Chair of the 1952 meeting was R.N. Chopra, the expert who had represented British India at the League of Nations meetings before the Second World War and who now represented independent India as the Director of the Drug

14 UK National Archives (NA), Home Office (HO) 45/24948. Note by J.H. Walker, 3rd July 1952. It is worth noting that the only other evidence of an urgent problem with cannabis consumption produced by the Secretariat in its report was the annual reports of the USA for 1936 and 1937 and P. Wolff s book Marihuana in Latin America: The threat it constitutes (Washington, 1949). The reliability of this volume was called into question at the trial of Backary Manneh discussed in chapter 3 of Mills, Cannabis Nation.

15 BL, UN, E/CN.7/262. Commission on Narcotic Drugs Report of the Eight Session, p. 16.

16 BL, UN, E/CN.7/276. The Problem of Cannabis, Note by the Secretary-General 22nd March 1954, p. 1.

17 Expert Committee on Drugs Liable To Produce Addiction, Third Report (Geneva: WHO Technical Report Series no. 57, 1952), p. 11. 
Research Laboratory at Srinigar in Kashmir. Among the other members was the British expert J.R. Nicholls of the Government Laboratory in London and the American, N.B. Eddy of the National Institutes of Health in Bethesda. This group had provided a clear and definitive position on the therapeutic use of cannabis, and this was as negative as could be. It was also on the advice of this committee that the term 'cannabis' came to replace 'Indian hemp' in UN discussions and regulations. ${ }^{18}$

The Commission returned to the issue of cannabis on $22^{\text {nd }}$ April 1954 as the Secretariat was keen to draw attention to the WHO's 'clear-cut position in the matter [that] there was no justification for the medical use of cannabis preparations'. The representative of the Secretariat did concede that preparations of the plant remained in the pharmacopoeia of a number of countries, but was quick to confirm that it was not mentioned in many others. The WHO representative at the meeting piped up to point out that presence in the pharmacopoeia was not evidence of actual usage. ${ }^{19}$ He reiterated that 'from a medical point of view it could be said that cannabis preparations no longer served any useful purpose'. The British representative returned to the issue of corn plasters that had haunted the country's position on cannabis since the 1920 s, before Harry Anslinger ${ }^{20}$ of the USA made his nation's position plain 'stocks held by pharmacies in the United States had been turned over to the public authorities upon enactment of the Cannabis Tax Act. Cannabis was no longer used in the country'. It only remained for Mr Yates of the Secretariat to confirm that he agreed with the WHO representative that for all practical purposes cannabis preparations were no longer necessary. The mention in various pharmacopoeia showed, however, that there was still a residual situation to clear up, including the use of cannabis for veterinary purposes.

The Chairman, the French representative, proposed that a resolution be drawn up to recognise the emerging consensus at the Commission that cannabis had no legitimate medical use. Those present endorsed the proposal. The Commission now had a clear position on the medical use of cannabis which it had taken straight from the WHO's work in the previous year. It was a position taken by the Commission without any clear sense of what evidence the WHO had used, and without recourse to any scientific data of its own. ${ }^{21}$

South Africa was the first to respond to the Secretariat's earlier call for more information from countries where cannabis use was common. It sent in an extended

18 BL, UN, E/CN.7/262. Commission on Narcotic Drugs Report of the Eight Session, p. 16.

19 The WHO representative was Pablo Osvaldo Wolff. See footnote 14.

20 Anslinger remains a controversial figure in the history of drugs. See McAllister, Drug Diplomacy, p. 89.

21 This account taken from BL, UN E/CN.7/SR231 Commission on Narcotic Drugs Summary of the 231st Meeting on 22nd April 1954, pp. 5-6. 
version of a report it had previously submitted in 1952 to the WHO. ${ }^{22}$ The authorities in South Africa had a long history that stretched back into the nineteenth century of concern about cannabis consumption among both the Asian and African communities there. Indeed, it was a report from the Union of South Africa in 1923 that had placed cannabis for the first time on the League of Nations drug control agenda. ${ }^{23}$ As such it was not surprising to find that their position was a negative one. Delegates at the meeting who discussed the document were especially struck by reports of cannabis users who were as young as seven, and by the fact that a staggering two hundred and twenty-nine tons of cannabis had been seized in 1952. Harry Anslinger launched into an attack on the South African government for being too lenient in its approach, claiming that it was regrettable that the police did not pay more attention to drug addiction and illicit traffic and that there was not a special narcotics police division in the Union'. This despite the fact that eighteen thousand prosecutions for cannabis offences had been made there in 1952. Only the Indian delegate was intrigued by reports of use of preparations of the plant in South Africa's indigenous medical systems and he asked for more information about consumption of the drug there at social and ceremonial occasions. ${ }^{24}$

\section{Cannabis and non-Western medicines}

When the Commission met in 1955 it was greeted with new evidence on cannabis from the WHO and others. The Greek representative submitted a statement to the Commission on the question of cannabis that included the following assertions; 'there is a relation between the degree of unemployment and the use of charas, especially in the case of the eastern peoples' and 'apart from the permanent disturbance of their mental faculties, charas users have a propensity to crime and rapidly become dangerous criminals'. $25 \mathrm{He}$ included no evidence to support his statements and provided no evidence of citations to studies that had formed his position. His document was accompanied by something rather more significant. The WHO submitted its definitive statement on The Physical and Mental Effects of Cannabis for consideration. It was authored by Pablo Osvaldo Wolff, a former Secretary of the Expert Committee on Addiction Producing Drugs of the WHO. It

22 Union of South Africa, Report of the Inter-Departmental Committee on the Abuse of Dagga (Pretoria: Government Printer, 1952).

23 See J. Mills, Cannabis Britannica: Empire, trade and prohibition 1800-1928, (Oxford, 2003), pp. 160-2.

24 This account taken from BL, UN, E/CN.7/SR231. Commission on Narcotic Drugs Summary of the 231st Meeting on 22nd April 1954, pp. 7-12. Greece.

25 BL, UN, E.CN/7/L.92. The Question of Cannabis, Note by the representative of 
was damning in its revelations and in its tone, and drew on over fifty publications and scientific papers to support its argument. He was scarcely interested in its physical effects, referring readers to previous publications by Bouquet that made it clear that 'among cannabis smokers diseases of the respiratory tract are frequent, bilharsiasis and circulatory as well as alimentary diseases become refractory etc'. It was with its mental effects that he was most concerned. He ranged widely across the work of others and lifted their observations on varied conditions such as 'transitory intoxication', 'mania from hasheesh', 'acute psychosis associated with the withdrawal of cannabis indica from addicts' or 'a certain link between chronic cannabis consumption and the atypical schizophrenic picture'. He made it clear that he had no time for those who would 'minimise the importance of smoking marihuana'. As such he went beyond his remit to outline the social impacts of cannabis use, quoting reports from Greece, South Africa, Puerto Rico and Mexico which insisted that 'cannabis apparently brings to the surface of the subconscious vices and tendencies which have been submerged by education and environment'.

As these reports were thin on actual examples and instances, Wolff drew on his collection of "clippings from newspapers from South American countries which suffer particularly from the consequences of marihuana abuse, and which the writer has been collecting for years'. Clearly conscious of how tenuous this looked, he was forced to admit that these were 'somewhat sensational' in character, but he made a point of insisting that the recurrence of such stories, as well as the police statements referred to within them 'show that there must be much truth in them'. Having done this, he did not hesitate to select the most startling of the stories, including a case where the murder of a petrol station attendant by a group of sixteen year olds had been blamed on their cannabis consumption. Despite acknowledging the weakness of such evidence he left colleagues in no doubt about the 'criminogenic influence of the cannabis resin' and he concluded that 'cannabis constitutes a dangerous drug from every point of view, whether physical, mental, social or criminological'.

The document is remarkable in its relentless insistence on that conclusion. Various criticisms have been made of the report and of the author. His reliance on data from newspapers was regarded as sufficient to dismiss his views by a British doctor in a court of law who was asked to comment on his conclusions at a murder trial in the early $1950 \mathrm{~s}^{27}$ At least some of the work that he refers to is problematic, not least of all that by Anslinger, and by Warnock. ${ }^{28}$ Whatever the shortcomings of

26 BL, WHO/APD/56. The Physical and Mental Effects of Cannabis, Additional Study, 17th March 1955, p. 32.

27 See chapter 3 of Mills, Cannabis Nation.

28 See R. Bonnie and C. Whitebread, The Marihuana Conviction: a history of marihuana prohibition in the United States, (Charlottesville, 1974), pp. 154-174; J. Mills, "Colonial Africa and the international politics of cannabis: Egypt, South Africa and the origins of global control" in J. 
Wolff s WHO document, it is important for this study as it shows that by the middle of the 1950s it was opponents of cannabis use who had control of its agenda, however outlandish their statements and dubious their evidence. When the Commission turned to the WHO for a definitive expert position from the medical authorities, it received a statement from one of most firmly established critics of the drug of the period. Mr Yates of the Secretariat commended Wolffs report to the Commission as he felt that it "embodied not only a statement of the facts, but also a number of critical evaluations'. ${ }^{29}$ The Chair of the Commission, the French representative Charles Vaille, and Harry Anslinger were careful to publicly record their appreciation of Wolffs efforts. It was agreed that his account should be forwarded with the report of the Commission to its parent body, the UN's Economic and Social Council. ${ }^{30}$

The Commission had endorsed the WHO's position in 1954 that 'from a medical point of view it could be said that cannabis preparations no longer served any useful purpose'. With Wolff's report from the WHO at hand in 1955 the Secretariat was finally able to move the Commission to accept the first alternative of the draft single convention on cannabis that had been presented in 1950. Based on the premise that cannabis had no legitimate medical use that could not be met by other "less dangerous substances', the Commission approved the proposal that the production of the plant for purposes of manufacturing drugs should be entirely prohibited save for those small amounts necessary for scientific experimentation. ${ }^{31}$

That was not quite the whole story, however, as the agreement included controversial exceptions for India. In 1955 that country's representative had arrived at the meeting to declare that

his Government was unable at present to comply with [the] Council resolution ... as cannabis was used in both the unani and ayurvedic systems of indigenous medicine, by which a very large proportion of the Indian population was treated. Unless the possibility of discontinuing the use of cannabis in these systems had been studied by the Indian medical faculties- and there had not been sufficient time for this since the Council issued its recommendation- immediate implementation of the recommendation was not possible. He wondered whether the World Health

H. Mills and P. Barton, eds, Drugs and Empires: Essays in modern imperialism and intoxication, $c$. 1500-c. 1930, (Basingstok 2007), pp. 178-182.

29 BL, UN,E/CN.7/SR 266. Commission on Narcotic Drugs Tenth Session Summary of the Two Hundred and Sixty-Sixth Meeting 20th April 1955, p. 14.

30 BL, UN, E/CN.7/SR 267. Commission on Narcotic Drugs Tenth Session Summary of the Two Hundred and Sixty-Seventh Meeting 21st April 1955, p. 4.

31 Commission on Narcotic Drugs, Report of the tenth session, (New York 1955), p. 12. 
Organization or any other expert body had given consideration to the question of the utilization of cannabis in indigenous systems of medicine. ${ }^{32}$

The WHO's representative was caught on the hop. He replied that 'he was unable to state the position of his organization with regard to the use of cannabis in indigenous medicine' and contented himself by repeating the doctrine that 'cannabis should be abolished from all legitimate medical practice'. The Indian delegation insisted that the use of cannabis in non-Western systems of medicine should be acknowledged as legitimate and that exceptions would be required to allow for this. This position echoed that of the delegation's British predecessors at the Hague Opium Conference in 1924/5. Any agreement on cannabis would have to work around south Asia's long experience of using preparations of the plant. ${ }^{33}$

The Indian effort to have practices in south Asia validated by the UN caused consternation. The Yugoslavian representative was worried about the effect of entering reservations, and the Mexican delegate insisted that 'his delegation in principle favoured total prohibition' as he was anxious that 'the danger that production permitted in exceptional cases might be exported to other countries must be avoided'. The representative of the USA was adamant that Asian therapeutic traditions should be dismissed as 'quasi-medical uses'. This provoked a fierce rebuke from Saldanha of the Government of India;

Indigenous systems of medicine such as the Ayurvedic and Unani systems which had been in existence in India on an organized basis for hundreds of years, and on which large sections of the population continue to depend for medical treatment, were just as much entitled to be called medical, and not quasi-medical, as the allopathic and homeopathic systems were. They did not become quasi-medical merely because they were not Western systems. ${ }^{34}$

Eventually the Government of India succeeded in forcing the UN to recognise as legitimate the production of cannabis for non-Western medical systems. In $1957^{\text {' the }}$ Commission adopted a compromise proposal whereby the abolition of the medical use of these substances, except in three indigenous medical systems- the Ayurvedic, Unani and Tibbi systems, was recommended to Governments'. ${ }^{35}$ This was a significant achievement. The Indian delegates had frustrated the efforts of the Secretariat and the WHO to declare that cannabis was of no medical value

32 BL, UN, E/CN.7/SR 267. Commission on Narcotic Drugs Tenth Session Summary of the Two Hundred and Sixty-Seventh Meeting 21st April 1955, p. 6.

33 See Mills, Cannabis Britannica, p. 174

34 BL, UN, E/CN.7/SR 270. Commission on Narcotic Drugs Tenth Session Summary of the Two Hundred and Seventieth Meeting 22nd April 1955, pp. 3-5.

35 BL, UN, E/CN.7/333. Report to the Economic and Social Council on the twelfth session of the Commission on Narcotic Drugs, p. 81. 
whatsoever. It had also challenged the hegemonic assumptions of the Westerntrained doctors of the WHO about the legitimacy of south Asian medical systems. It should be emphasised, however, that it was the interests of 'large firms which produced indigenous medicines ${ }^{36}$ that were being protected in India rather than those of the humble bazaar herbalist.

By 1957 the Commission had also moved on to consider the surveys of the cannabis situation that had been commissioned by the WHO back in 1953 and which had focused on the most important centres of consumption such as South Africa, India, Brazil and Morocco. ${ }^{37}$ Each of these reports conformed to a set format, so that data was collected from different contexts in order to be readily compared. The first set of questions related to the plant itself, the second to the industrial outputs from the plant. The third looked at the legal uses to which psycho-active preparations were put, the fourth to any international trade in cannabis plants, the fifth to medicinal use which was followed by details of non-medical use. The rest of the questionnaire focused on matters relating to illegal traffic, including surveillance and police measures. The surveys were designed to give a sense of what the existing legitimate interests were in the plant, and of the difficulties that were being experienced in controlling its illegitimate use.

As such most of the reports simply repeated the common mantra that possession and consumption of cannabis were illegal, that the police worked hard to arrest consumers and peddlers, and that traffic in the drug was troublesome. For example, the report from Brazil noted that 'cultivation of the cannabis plant is most prevalent in the northern and northeastern parts of the country' and that the traffic flowed from 'the backlander who cultivates the cannabis plant through the middleman to the ultimate users ... Braganca, a city in Northern Brazil ... is one of the largest centres of the cannabis traffic in that part of the country'. It assured readers that 'as the State and Federal authorities are fully aware of the existence of the illicit traffic in and use of cannabis in Brazil and as they know the places where these mainly occur, their concerted drive against the spread of the traffic in and use of the drug has not slackened'. However, the report was forced to admit that such was the extent of consumption that it was 'not possible to give even a rough estimate of the number of maconha smokers in Brazil'. ${ }^{38}$ The report from Southern Rhodesia similarly intoned that "police patrol all native areas regularly, and any cannabis plants are

36 BL, UN, E/CN.7/SR.286, p. 12.

37 By 1960 replies were circulated from the Union of South Africa, Basutoland, Bechuanaland, Swaziland, Northern Rhodesia, Southern Rhodesia, Brazil, Angola, Mozambique, Morocco, India, Pakistan, Italy, Egypt, Costa Rica, Burma, Lebanon, Mexico, USA, Jamaica, Cuba, the Dominican Republic, Haiti and Greece.

38 BL, UN, E/CN.7/286/Add.8. Survey of the situation in Brazil, 19th April 1955, pp. 8-17. 
destroyed and the grower prosecuted ${ }^{39}$ and at the opposite end of the continent, the authorities lamented that 'at one time packets of kif were found in family parcels sent to Moroccan soldiers serving in Europe by their families'. ${ }^{40}$ These glimpses of obstinate consumers and persistent markets suggest that there was ongoing resistance to, or ignorance of, attempts to prohibit use of a favourite intoxicant in many parts of the world;

Group smoking is general ... the pleasure seems to lie not only in the use of the drug but also in the collective euphoria it produces. This they smoke in cafes, sometimes in a private house, very often on a small shopkeeper's premises. This small shopkeeper is very often a barber or tailor. The master craftsman smokes with his staff or forms groups with his customers, to whom, it is said, he gives the drug and equipment free of charge solely for the pleasure of smoking in company ... kif addicts only incur the half-hearted disapproval of the healthy members of the population. The fact that the use of kif is so widespread and taken for granted most certainly influences their views: a practice as common and as widely tolerated as this could not be regarded as a very serious offence or the drug a very harmful product. ${ }^{4}$

While the above report from French Morocco pointed to the place of cannabis consumption in the routine social life of the region, the survey of Brazil identified the place of the drugs in the country's cultural practices,

In Alagoas the drug is used during sambas and batuques, dances introduced by Negroes: it is also consumed by those who porfiam na colcheia i.e. contend with semi-breves, which among country folk is a rhymed and sung dialogue in which each reply (usually in quatrains) begins with the challenger's cue or last words. It is claimed that the cannabis gives contestants great inspiration and facility in rhyming and leads them to issue the challenges for the desafio or poetic duel. ${ }^{42}$

This contrasted somewhat with the picture in Southern Rhodesia where it was used before going into battle, and more recently before hunting expeditions and sporting events' ${ }^{43}$ Similar applications were encountered in India where it 'is still sometimes used by contestants in wrestling contests and other athletic sports as well as in games requiring great effort and endurance'. In that country it was reported 'that to meet

39 BL, UN, E/CN.7/286 Add.7. Survey of the situation in Southern Rhodesia, 30th March 1955, p. 4.

40 BL, UN, E/CN.7/286/Add.11. The cannabis situation in the Scherifian Empire (French Zone), 20th April 1956, p. 12.

41 Ibid., pp. 10-11.

42 BL, UN, E/CN.7/286/Add.8. Survey of the situation in Brazil, 19th April 1955, p. 14.

43 BL, UN, E/CN.7/286 Add.7. Survey of the situation in Southern Rhodesia, 30th March 1955 , p. 9. 
a man carrying bhang was regarded as an omen of success; similarly to think of the cannabis plant in a dream was considered lucky'. This was because the cannabis plant was represented in Hindu holy texts as sacred. ${ }^{44}$ Such glimpses add to the sense that the picture presented in these reports was of a police problem rather than a social problem. In other words, the regulations on cannabis since the 1920s had imposed a new set of obligations on the authorities rather than it being the case that the behaviour of cannabis consumers had forced officials to act. Poetry contests, folk dances, sporting events and afternoon gatherings at the local shop hardly look like the stuff of social mayhem given the wider history of the 1950s. Needless to say none of these glimpses of routine cannabis consumption were singled out for discussion by the Commission. Delegates had reports from eighteen countries in front of them and lingered for little more than an hour and a half in chewing them over. Much of this limited deliberation was taken up by the Indian delegate's report on a meeting in his country of that year and some excitement about mixtures of hashish and chocolate available in Arab countries.

That the glimpses of routine users of cannabis engaged in harmless activities were not discussed and were disregarded as evidence may well be down to another of the documents that accompanied the national surveys for consideration in 1957. The Secretariat presented its summary of where the Commission had reached on cannabis as it entered the final phase of re-drafting the Single Convention. It quoted Wolff s conclusion that cannabis drugs were dangerous from 'every point of view' and added its own assertion that 'they are used for euphoric purposes in many parts of the world where their consumption constitutes a traditional and widespread habit and often a serious social evil'. ${ }^{45}$ The same report was forced to admit that

While cannabis drugs are addiction producing within the meaning of this term as defined by the $\mathrm{WHO}$, it is agreed that they do not cause physical dependence in the same way as morphine, i.e. that there are no physical abstinence symptoms equivalent to those which occur in the case of withdrawal of morphine

The issue of addiction was yet to be discussed by the Commission and as such it recommended that further attention be paid to the 'special character of addiction to cannabis drugs'. The only reference to this point in the Commission's thoughts on their report was the observation by Harry Anslinger that 'medical officials of the United States Air Force had held that, contrary to the assertion ... cannabis caused

44 BL, UN, E/CN.7/286 Add.12. Survey of the situation in India, 30th April 1956, pp. $26-29$.

45 BL, UN, E/CN.7/324. The Question of Cannabis, Note by the Secretary-General, 26th April 1957, p. 11. 
physical dependence'. He had to acknowledge, however, that 'their theory had been challenged'. ${ }^{46}$

\section{Cannabis and the Single Convention}

The uneasy consensus on the medical obsolescence of cannabis that the WHO and colleagues in the UN had worked so hard to establish in the 1950s faced a final challenge late in the decade, this time from the microbial world. British delegates, together with those from the US, Canada and France, tabled a draft resolution in April 1959 which pointed to recent reports of the antibiotic properties of certain extracts of the cannabis plant. They were mindful of the fact that these antibiotic properties could undermine the WHO's insistence that cannabis was no longer a useful source of medicine and therefore requested the organisation to prepare an account of antibiotic properties in cannabis as a matter of urgency. ${ }^{47}$ The French delegate acted as a spokesman for the group that had introduced the resolution and he asserted that new techniques, such as ionising radiation, meant that cannabis might now be used to produce useful drugs. He pointed to reports of experiments in Hungary which suggested that cannabis was the source of substances that were effective against staphylococcus aureus and various gram-positive bacilli. The American delegate was insistent that 'the door should not be closed to further research on any natural material which might be of use to the medical profession' and in a rare show of unity the USSR and China supported the draft resolution of the US, the UK, Canada and France, as did others including India and Iran.

While governments such as the US and the USSR had been entirely convinced that the plant had no legitimate medical uses throughout the 1950s it is striking that the mention of antibiotics had rapidly caused them to reconsider. This was because, since the development of mass production techniques for penicillin in the 1940s, such products had been widely regarded as the wonder-drugs of their generation which were capable of controlling an array of infectious diseases for the first time. The economic and political power that such control could confer was highly attractive to national governments and the development of new and improved pharmaceutical products, particularly antibiotics, was high on the scientific agendas of many modern states in this period. ${ }^{48}$ This context explains the readiness of so many nations to back the draft resolution asking the WHO to investigate reports of antibiotic properties in cannabis more closely.

46 BL, UN, E/CN.7/SR.342. Commission on Narcotic Drugs Twelfth Session Summary of the Three Hundred and Forty-Second Meeting, 6th May 1957, p. 5.

47 BL, UN, E/CN.7/L.212. The Question of Cannabis, 30th April 1959.

48 For more on the origins and impact of antibiotics in this period see R. Bud, Penicillin: Triumph and Tragedy, (Oxford, 2007). 
The WHO response to this sudden show of unity on the part of the Commission's members reads as one of piqued professional pride. Dr Halbach, the representative of the organisation at the Commission, blustered that he was convinced that the Expert Committee's statement on the obsoleteness [sic] of cannabis as a therapeutic agent would remain unchanged' and pointedly asserted that 'it was not easy to imagine, in the present state of knowledge, the reintroduction of cannabis as a means of rational therapy based on modern conditions'. His reluctance comes across in the minutes, as he conceded that 'he felt that the WHO would have to carry out the study desired by the Commission. ${ }^{49}$ Halbach was the chief medical officer of the addiction-producing drugs section of the WHO and evidently did not take kindly to diplomats challenging statements on medicines that were designed by his fellow scientists to be final and authoritative.

The WHO response finally appeared late in 1960 as a paper with the title 'The Merits of Antibiotic Substances Obtainable from Cannabis Sativa'. The report noted that results published between 1957 and 1959 from experiments with extracts of cannabis had indeed suggested antibacterial activity. These results supported the theory that such extracts inhibited the growth of staphylococci, streptococci and other Gram-positive organisms and actively destroyed the tubercle bacillus. However, the WHO paper went out of its way to problematise these results. It questioned the validity of the experiments and argued that 'none of the available reports on clinical use appears to refer to a properly conducted trial with adequate controls'. It pointed out that 'no experiments are reported on its effects on isolated mammalian cells'. It noted that 'it would appear that these studies, which have been going on for several years, have not carried enough conviction to induce a material production of this substance on a commercial scale'. Finally it speculated that

Even if the clinical reports in the publications under survey are to be fully credited, it still remains to be decided whether they illustrate a curative action not obtainable by other and more orthodox means ... it would be very surprising if a direct comparison between them [neomycin and bacitracin] and the cannabis substances in question did not show that their action, especially if they were used together, was superior.

The report reads as a hatchet job as it questioned the legitimacy of the science behind the positive reports with no good reason, inferred that lack of a corporate backer was evidence of ineffectiveness on the part of a substance, and speculated on the likely results of an imaginary trial of cannabis antibiotics against those already available to conclude that the latter were superior to the former. Any chance that the imaginary trial would take place was denied by the report's assertion that 'the case has not been

49 BL, UN, E.CN/7/SR.422. Commission on Narcotic Drugs, Fourteenth Session, Summary of 421st Meeting, 4th May 1959, pp. 3-13. 
proved in favour of making cannabis available for the extraction of therapeutic substances, particularly with antibiotic properties equal of superior to those obtainable otherwise'. It finished by referring the reader back to the report of the WHO Expert Committee of 1952 and confirming that 'cannabis preparations are practically obsolete and there is no justification for their medical use. ${ }^{50}$

At the same time as the $\mathrm{WHO}$ was producing this report the Secretariat authored a final survey of the cannabis issue designed to inform delegates as they began to work on the agreement that would become the 1961 Single Convention. This was largely a compilation of observations from the country surveys on the subject conducted since 1952. It is instructive to read the summary against the originals, as the selective nature of the document seems obvious. Consumers from across the continents were lumped together in the following brief description;

Apart from unemployed persons who generally figure prominently among consumers, there are also mentioned traffickers who also consume the drug, labourers, odd-jobbers, vagrants, criminals, seamen and a few students and cabaret artists.

Nowhere was there mention of the shopkeepers and craftsmen who smoked in the Moroccan afternoon, of the Brazilian country-festivals where cannabis was inhaled to encourage dancing and poetry, or of the Indian and African sports for which contestants prepared with a dose of the drug. ${ }^{51}$ Instead, the Secretariat's survey carried details of an ambitious new development that neatly summarises the position of the UN on cannabis by this time. As part of its Mediterranean Development Project scheme $\$ 703000$ had been provided to 'assist the Government of Morocco with two concurrent phases of its plans to develop the Rif region ... which includes a large part of the lands traditionally cultivated for kif (the chopped up parts of the flowering or fruiting tops of the cannabis plant)'. ${ }^{52}$ For the first time the organisation was involving itself in a hands-on programme of eradicating cannabis production, through replacing it with 'forest and fruit-tree planting, livestock raising, and field crops'.

Finally, a Plenipotentiary Conference was convened at which delegates were expected to thrash out the details of the Single Convention. The WHO and the Secretariat of the UN had made their positions on cannabis clear. The 1950 proposal to entirely prohibit the production of cannabis save for the small amounts necessary

$50 \mathrm{BL}, \mathrm{UN}, \mathrm{E} / \mathrm{CONF} / 34 / 5$. The Merits of Antibiotic Substances obtainable from Cannabis Sativa, pp. 2-3,

51 BL, UN, E/CN.7/399. Annex The Question of Cannabis, Note by the SecretaryGeneral 5th December 1960, p. 9.

52 BL, UN, E/CN.7/399. The Question of Cannabis, Note by the Secretary-General, 5th December 1960, p. 7. 
for scientific experimentation was presented as article $39 .^{53}$ At this stage a number of governments acted to prevent this position being adopted in the final draft, and one of these was the UK. The British position was not taken out of any great concern about cannabis and the preparations of the plant, but rather was driven by suspicion of the political principles that lay behind the proposals. It was not alone, as a number of governments were outraged at the suggestion that the UN had the power to determine the domestic affairs of national states, or as the UK's delegate pointed out:

\begin{abstract}
It is, in her Majesty's Government's view, wrong in principle, in a matter which affects the treatment of the sick, to require governments, if they wish to adhere to the Convention, to consent to the prohibition of whatever drugs a majority at a plenipotentiaries' conference may decide to include ... a mandatory prohibition of internal manufacture and use such as is contained in paragraph 1 of Article 2 seems to Her Majesty's Government to be quite unjustifiable.
\end{abstract}

The British position was that, unless modifications were made which gave the final decision on the scientific and medical use of any drug to individual national governments, the UK would not agree to the Convention.

The proposals on cannabis were also a sticking point for the Government of India for the simple reason that they entirely ignored the earlier discussions about Asian medicines. The Indian delegates there opposed Article 39, insisting again that 'cannabis drugs are used in indigenous systems of medicine in India and it has not yet been proved that these drugs are as dangerous as the other drugs listed in the Schedule or total prohibition of these drugs is absolutely necessary'. ${ }^{55}$ Iran backed this position and submitted an amendment to the cannabis section of the treaty that read 'the parties shall prohibit the production of cannabis and cannabis resin, except for purposes of their use in indigenous medicine or of scientific research' ${ }^{56}$ Harry Anslinger of the US government even contributed on the side of cannabis, stating that 'a product derived from the cannabis plant was thought to have possibilities for the treatment of certain mental diseases..$^{57}$ On the other hand many nations held an unblinking view of the drug and the representative of Egypt 'urged countries in

53 BL, UN, E.CN.7/AC.3/9. The Single Convention on Narcotic Drugs (Third Draft), 11th September 1958, p. 55.

54 BL, UN, E/CONF.34/1. Compilation of comments on the single convention (Third draft), p. 40.

55 BL, UN, E/CONF.34/1. Compilation of comments on the single convention (Third draft), India on Schedule IV.

56 BL, UN, E/CONF.34/1. Compilation of comments on the single convention (Third draft), Iran: amendment to the redraft of article 39.

57 BL, UN, E/CONF.34/24. UN Conference for the Adoption of a Single Convention on Narcotic Drugs, Summary Records of Plenary Meetings, Thirty-Third Plenary Meeting 20th March 1961, p. 154. 
which the cannabis plant was cultivated to assume the obligations set forth in article 39 ' while the Brazilian made it clear that 'his delegation was ... in full agreement with article 39 as it stood' ${ }^{58}$ The Commision's response to this divided position on the issue of cannabis was to send it to an Ad Hoc Committee which included representatives from India, Pakistan, the US, the UK and Canada. ${ }^{59}$

In advance of the meeting of this Committee the British and Canadian delegates drafted a much simplified version of the article on cannabis. Their intention was to place preparations of the plant alongside opium in the convention as a substance that could be prohibited in domestic medicine by national governments if they so wished. Most were satisfied with this but the Government of India insisted that the leaves of the cannabis plant should be excepted from any provisions on cannabis whatsoever, stating once again that they were 'far less harmful than alcohol and ... used by the poorer people of India to make a mildly intoxicating drink or as a substitute for analgesics and tranquillizers'. ${ }^{60}$ Once this was accepted by everyone it was agreed that 'cannabis leaves should be subject to a less rigid regime than the fruiting or flowering tops or the resin of the cannabis plant ... it was proposed to this end [that] the leaves may be omitted from the definition of cannabis and that a separate provision may provide for their control'. ${ }^{61}$ The British had seen off the ambition of the UN to dictate policies to national governments on medicines, and the Indians had ensured that cannabis leaves would be treated differently from other parts of the plant. The Conference finally agreed on cannabis in the afternoon of $20^{\text {th }}$ March $1961 .^{62}$

The Single Convention on Narcotic Drugs 1961 remains the basis of international laws on cannabis to this day and its key intention was to limit exclusively to medical and scientific purposes the production, manufacture, export, import, distribution of, trade in, use and possession of drugs'. Specific measures included prohibiting in the name of public health the cultivation of cannabis plants for anything but scientific and medical use, annual reporting on the area of cultivation of cannabis for these purposes, and establishing national agencies to control the cultivation of crops for medicinal and scientific purposes. Modern medicines that contained cannabis were in Schedule I of the Convention and their prohibition was not recommended.

58 BL, UN, E/CONF.34/24. UN Conference for the Adoption of a Single Convention on Narcotic Drugs, Summary Records of Plenary Meetings, Thirteenth Plenary Meeting, 8th February 1961, pp. 58-62.

$59 \mathrm{BL}, \mathrm{UN}, \mathrm{E} / \mathrm{CONF} .34 / 12$. UN Conference for the adoption of a single convention on narcotic drugs, ad hoc committee to deal with article 39, 23rd February 1961, p. 2.

60 BL, UN, E/CONF.34/24/ADD.1. Ad Hoc Committee on Article 39 of the Third Draft, Tuesday 21st February 1961, p. 274.

$61 \mathrm{BL}, \mathrm{UN}, \mathrm{E} / \mathrm{CONF} .34 / 12$. UN Conference for the adoption of a single convention on narcotic drugs, ad hoc committee to deal with article 39, 23rd February 1961, p. 2.

62 BL, UN, E/CONF.34/24. UN Conference for the Adoption of a Single Convention on Narcotic Drugs, Summary Records of Plenary Meetings, Thirty-Fourth Plenary Meeting 20th March 1961, p. 156. 
Cannabis and cannabis resin, however, were included in Schedule IV of the Convention, which meant that the prohibition of their medical use was recommended. Significantly, the definition for the sake of the treaty was as follows:

"Cannabis" means the flowering or fruiting tops of the cannabis plant (excluding the seeds and leaves when not accompanied by the tops) from which the resin has not been extracted, by whatever name they may be designated.

This was the section that meant that India's reservations about cannabis leaves had been respected and that the only stipulation regarding these was the vague assertion that 'The Parties shall adopt such measures as may be necessary to prevent the misuse of, and illicit traffic in, the leaves of the cannabis plant'.

\section{Conclusion}

Different governments held various positions on cannabis throughout the 1950s, and the actions of the Indian delegation show how a specific national interest could shape the final version of the 1961 Single Convention. However, the Indian intervention draws attention to a further feature of the international context in this period, one that was more pronounced in the 1950s than previously. This was the place of trans-national bodies such as the UN and the WHO in driving the agenda on drugs, and in particular on cannabis. Bodies such as the Expert Committee on Habit Forming Drugs at the WHO and the Secretariat at the United Nations were determined to assert the darkest picture possible of cannabis in this period and to force through the strictest possible control mechanisms.

The reasons that the UN and the WHO took such a dark view of cannabis are various. In the first place, the position of control-advocates in key roles and on important committees in these organisations ensured that negative views of a whole range of substances were the starting position for international discussions throughout the 1940s and 1950s. Moreover, both the UN and the WHO were nascent bodies that were engaged in carving out positions for themselves in the postwar world. Their interest in cannabis can be seen as just one instance of a wider project of empire-building and territory-claiming by the staff of ambitious organisations at a time when a growing remit for these bodies ensured their significance and survival. In the 1920s cannabis had first been caught up in the international regulatory system because of the competing interests of national and colonial governments such as the UK, the US, Egypt and India. In the 1950s cannabis was located closer to the heart of the international drugs agenda than ever before, and it was put there not by national governments, but by the UN and the 
WHO, trans-national bodies seeking to widen their spheres of interest by finding new problems that they claimed it was their responsibility to fix. ${ }^{63}$

James H. Mills is Professor of Modern History at the University of Strathclyde.

63 Perhaps the high point of this 'empire-building and territory-claiming' came in the early 1950s when Leon Steinig, head of the UN's Division of Narcotic Drugs, proposed that he would head up a world monopoly on opium, which he later sought to extend to cover nuclear material too. He was removed in 1952. For more on this, and for a full account of the politics of the international drugs bureaucracies in this period see McAllister, Drug Diplomacy, pp. 156-211. 


\section{References}

\section{Archives}

British Library (BL), League of Nations Collection (LN).

British Library (BL), UN Documents Collection (UN).

UK National Archives (NA), Home Office (HO) series.

\section{Published sources}

Bonnie, Richard and Charles Whitebread, The Marihuana Conviction: a history of marihuana prohibition in the United States. Charlottesville, 1974.

Lande, Adolf. "The Single Convention on Narcotic Drugs, 1961", International Organization, 16, (1962), 776-797.

Mills, James, Cannabis Britannica: Empire, trade and prohibition 180G-1928. Oxford, 2003.

Mills, James, "Colonial Africa and the international politics of cannabis: Egypt, South Africa and the origins of global control" in James Mills and Patricia Barton, eds, Drugs and Empires: Essays in modern imperialism and intoxication, c. 1506-c. 1930. Basingstoke, 2007.

Mills, James, Cannabis Nation: Control and consumption in Britain, 1928-2008. Oxford, 2012.

McAllister, William, Drug Diplomacy in the twentieth-century: An international history. London, 2000.

UN, The UN and Narcotic Drugs: Half a century of successful struggle against crime, disease and social affliction. New York, 1960.

Union of South Africa, Report of the Inter-Departmental Committee on the Abuse of Dagga. Pretoria: 1952.

WHO, Expert Committee on Drugs Liable to Produce Addiction, Third Report. Geneva, 1952.

Wolff, Pablo Marihuana in Latin America: The threat it constitutes. Washington, 1949. 